\title{
Correction: External beam radiotherapy versus vaginal brachytherapy in patients with stage II endometrial cancer: a systematic review and meta-analysis
}

Narasimhulu DM, Cope A, Riaz IB, et al. External beam radiotherapy versus vaginal brachytherapy in patients with stage II endometrial cancer: a systematic review and meta-analysis. Int J Gynecol Cancer 2020;30:797-805.

Since the online publication of this article, the authors have noticed that the author name 'Hassan Murad' is incorrect. The correct author name is 'Mohammad Hassan Murad'.

(C) Author(s) (or their employer(s)) 2020. No commercial re-use. See rights and permissions. Published by BMJ. Int J Gynecol Cancer 2020;30:1265. doi:10.1136/ijgc-2020-001199corr1

A) Check for updates 